\title{
Proliferative kidney disease in brown trout: infection level, pathology and mortality under field conditions
}

\author{
Heike Schmidt-Posthaus ${ }^{1, *}{ }^{,}$Regula Hirschi ${ }^{1}$, Ernst Schneider ${ }^{2}$ \\ ${ }^{1}$ Centre for Fish and Wildlife Health, Department of Infectious Diseases and Pathobiology, University of Berne, \\ Laenggassstrasse 122, PO Box 8466, 3001 Berne, Switzerland \\ ${ }^{2}$ Alte Landstrasse 156, 8800 Thalwil, Switzerland
}

\begin{abstract}
Proliferative kidney disease (PKD) is an emerging disease threatening wild salmonid populations. In temperature-controlled aquaria, PKD can cause mortality rates of up to $85 \%$ in rainbow trout. So far, no data about PKD-related mortality in wild brown trout Salmo trutta fario are available. The aim of this study was to investigate mortality rates and pathology in brown trout kept in a cage within a natural river habitat known to harbor Tetracapsuloides bryosalmonae. Young-of-the-year (YOY) brown trout, free of $T$. bryosalmonae, were exposed in the River Wutach, in the northeast of Switzerland, during 3 summer months. Samples of wild brown trout caught by electrofishing near the cage location were examined in parallel. The incidence of PKD in cage-exposed animals (69\%) was not significantly different to the disease prevalence of wild fish (82 and $80 \%$ in the upstream and downstream locations, respectively). The mortality in cageexposed animals, however, was as low as $15 \%$. At the termination of the exposure experiment, surviving fish showed histological lesions typical for PKD regression, suggesting that many YOY brown trout survive the initial infection. Our results at the River Wutach suggest that PKD in brown trout does not always result in high mortality under natural conditions.
\end{abstract}

KEY WORDS: PKD $\cdot$ Salmo trutta $\cdot$ Tetracapsuloides bryosalmonae $\cdot$ Mortality $\cdot$ Renal pathology Water temperature

Resale or republication not permitted without written consent of the publisher

\section{INTRODUCTION}

Proliferative kidney disease (PKD) is an emerging disease of wild and farmed salmonid fish in Europe (Okamura et al. 2011). The disease is caused by the malacosporean parasite Tetracapsuloides bryosalmonae, belonging to the Myxozoa (Hedrick et al. 1993, Canning et al. 2000, Okamura et al. 2001). The parasite's complex life cycle involves bryozoans as invertebrate hosts (Anderson et al. 1999, Longshaw et al. 1999, Okamura et al. 2001) and salmonids as vertebrate hosts (Feist \& Bucke 1993, Hedrick et al. 1993). Tetracapsuloides bryosalmonae infects salmonids through the skin and gills (Feist et al. 2001,
Longshaw et al. 2002) or the gills only (Morris et al. 2000, Grabner \& El-Matbouli 2010), and is afterwards distributed systemically. The main target organ in the fish host is the kidney (Kent \& Hedrick 1985), where it multiplies and differentiates from extrasporogonic stages in the renal interstitium to sporogonic stages in the lumen of renal tubuli (Kent \& Hedrick 1985). Spores are then excreted via the urinary system (Kent \& Hedrick 1985, Morris et al. 2002, Hedrick et al. 2004, Bettge et al. 2009). Transmission to bryozoans has been demonstrated in brown and brook trout (Morris \& Adams 2006, Grabner \& El-Matbouli 2008). In affected young-of-the-year (YOY) salmonids, proliferative and granulomatous nephritis and necrotiz- 
ing vasculitis with thrombus formation has been described (Hedrick et al. 1993, El-Matbouli \& Hoffman 1994, Bettge et al. 2009). Surviving fish show chronic lesions with interstitial fibrosis and tubulonephrosis, followed by a complete regeneration of renal morphology (Schmidt-Posthaus et al. 2012, 2013). The spread and outcome of the infection are suspected to be enhanced by water temperature, with severe disease and increased mortality at temperatures above $15^{\circ} \mathrm{C}$ (Wahli et al. 2008, Bettge et al. 2009, Okamura et al. 2011). In temperature-controlled aquaria, PKDassociated pathology and mortality are well documented in rainbow trout Oncorhynchus mykiss (Bettge et al. 2009, Schmidt-Posthaus et al. 2012). These studies showed mortality up to $85 \%$ at a constant water temperature of $18^{\circ} \mathrm{C}$. It is hypothesized that infection with $T$. bryosalmonae plays a significant role in the decline of wild salmonid populations, e.g. brown trout Salmo trutta fario in Switzerland and wild Atlantic salmon Salmo salar in central Norway (Wahli et al. 2002, Krkošek et al. 2007, Sterud et al. 2007). A widespread distribution of the disease in wild salmonid populations has also been shown in other countries (Dash \& Vasemägi 2014, Feist et al. 2002, Skovgaard \& Buchmann 2012). However, so far, these studies have only investigated prevalence, infection intensity and associated pathology under field conditions. Mortality rates and causes of mortality or contributing factors have not been evaluated and are still under debate (Dash \& Vasemägi 2014, Skovgaard \& Buchmann 2012).

The aim of the present study was to investigate PKD-related pathology and mortality in YOY brown trout Salmo trutta exposed in a cage experiment to river water within their natural environment. Specifically, the following questions were investigated: (1) does infection with $T$. bryosalmonae cause mortality in YOY brown trout under fluctuating temperature conditions as seen in the field? (2) Does infection with T. bryosalmonae cause pathology in cage-exposed brown trout comparable to that seen in wild-caught animals?

\section{MATERIALS AND METHODS}

\section{Study sites and fish sampling}

Experiments were conducted over a period of $3 \mathrm{mo}$ (16 July to 8 October 2013). The examined river system (Wutach) is situated in the southern part of Germany and has a $4.8 \mathrm{~km}$ border section to Switzerland in the midsection of the river. It passes through rural and urban areas before feeding into the larger River Rhine (Fig. 1A). The Wutach has several tributaries; one of these was included in this study (Ehrenbach) (Fig. 1A). Fish can migrate from the tributary into the Wutach but not vice versa because of an unpassable barrier. In former years, brown trout were regularly stocked in the Wutach (stocked fish originated from a trout hatchery nearby), but catches by anglers and
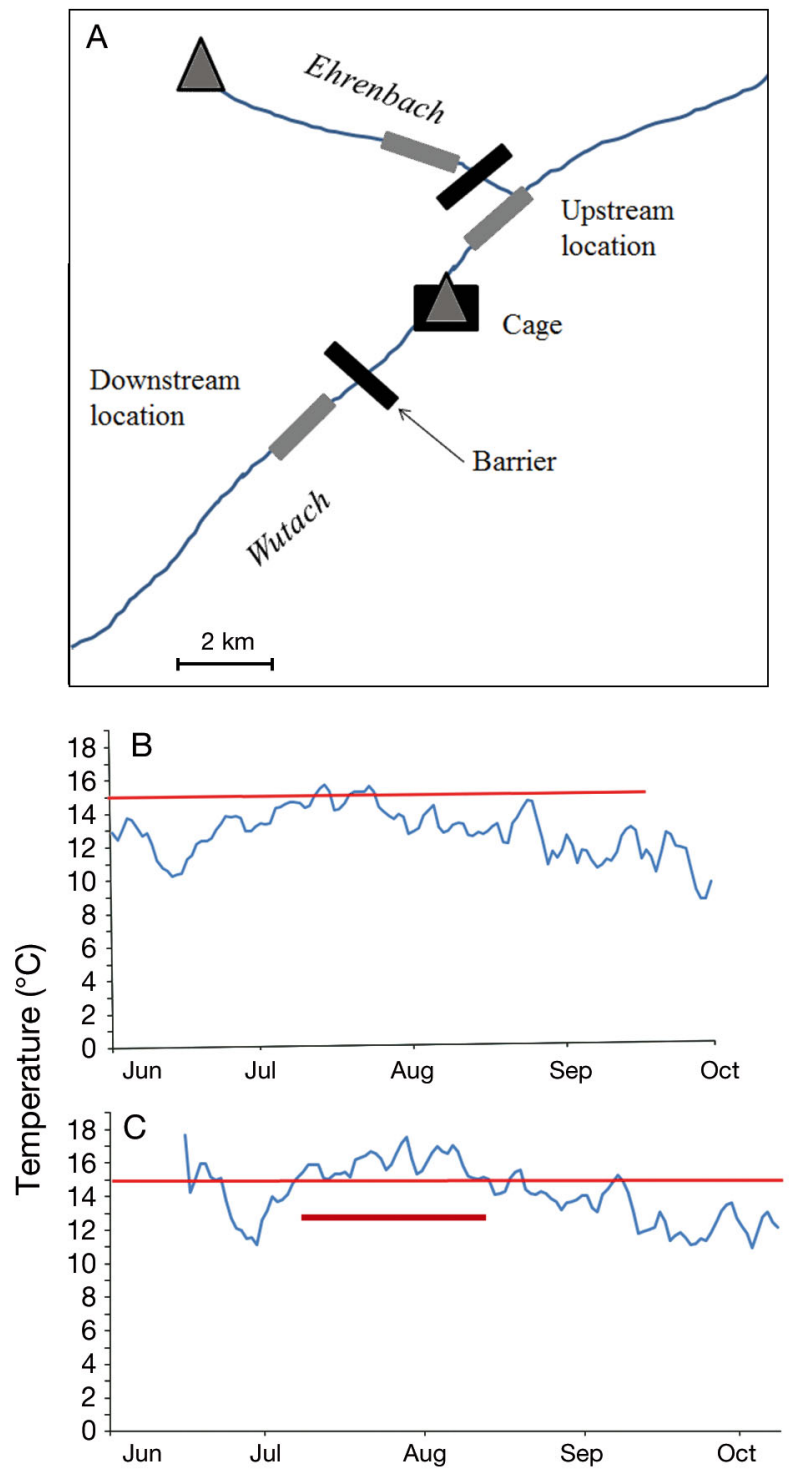

Fig. 1. (A) Location of field sampling sites (grey bars), cage (black rectangle) and temperature logger in the Wutach and Ehrenbach Rivers (grey triangles). Black bars indicate barriers that are not traversable by brown trout Salmo trutta fario. (B) Temperature curve in the Ehrenbach. (C) Temperature curve in the Wutach in the cage. Thin red lines indicate $15^{\circ} \mathrm{C}$, the critical water temperature for proliferative kidney disease-related clinical signs and mortality in trout. Thick dark line indicates period during which temperature stayed above $15^{\circ} \mathrm{C}$ 
electrofishing resulted in decreased numbers of fish in the midsection of the river (fishing statistics 19792013, Fischerverein Oberes Wutachtal unpubl. data). Stocking was stopped $1 \mathrm{yr}$ prior to the beginning of the experiment. Therefore, investigated animals from the field sampling originated from natural spawning. In the tributary (Ehrenbach) included in this study, a stable brown trout population was recorded (fishing statistics 1979-2013, Fischerverein Oberes Wutachtal unpubl. data) and no PKD records exist.

Investigations were conducted in 2 separate approaches: (1) a cage experiment was performed, exposing YOY brown trout for 3 mo to water in the Wutach; and (2) wild brown trout were sampled by electrofishing in 2 stretches in the Wutach and 1 stretch in the Ehrenbach (field sampling). Water temperature was measured inside the cage and at 2 locations in river water, in the Wutach and the Ehrenbach.

\section{Cage experiment}

A $1 \times 1 \times 0.5 \mathrm{~m}$ ( $1 \mathrm{~cm}$ diameter mesh size) cage was placed into the Wutach in the midstream part of the river (Fig. 1A). An additional mesh section was placed outside of the cage in the upstream position to avoid blocking of the cage by large floating debris. This mesh was cleaned regularly. During the experiment, the cage itself was not cleaned to avoid additional stress of the exposed animals. One hundred YOY brown trout were purchased from a trout hatchery. Offspring of various broodstock, originally deriving from the Wutach, were mixed on the farm. Animals used in this experiment therefore originated from various mother animals. To determine whether stocked fish were negative for infection with Tetracapsuloides bryosalmonae at the beginning of the experiment, 5 brown trout were euthanized in clove oil and immediately examined as described below. Ten brown trout served as a negative control and were kept in spring water at the hatchery of origin.

In the middle of July 2013, 85 brown trout were placed into the cage. They were fed $1 \%$ of their body weight with commercial fish food (TroCo Ultra, Coppens, pellet size $2 \mathrm{~mm}$ ) using an automatic feeding machine, ensuring continuous food supply. All fish were monitored daily for signs of disease or mortality. Moribund or dead fish were removed and investigated immediately. Three months after the start of the exposure experiment, all remaining trout were euthanized in clove oil, tagged and immediately investigated.

\section{Field sampling}

Fish were sampled at 2 stretches in the river Wutach, one stretch 2 to $3 \mathrm{~km}$ upstream of the cage experiment and one stretch 3 to $4 \mathrm{~km}$ downstream (Fig. 1A). Additionally, the tributary was sampled a few kilometres upstream of the entry into the River Wutach (Fig. 1A). In September 2013, 10 and 11 YOY brown trout, respectively, were sampled at each of the 2 sites in the Wutach and 15 YOY brown trout were sampled in the Ehrenbach by electrofishing. Due to the low density of YOY it was not possible to sample higher numbers of animals. Fish were euthanized separately in clove oil and examined as described below.

\section{Pathology, histopathology and immunohistochemistry}

The length of every dead or euthanized fish was recorded, followed by a complete necropsy. Animals originating from the cage experiment were weighed and the condition factor was calculated (100 $\times$ weight/ length ${ }^{3}$; Bagenal 1978). Macroscopic changes in the inner organs were recorded. Animals were then immediately fixed in $10 \%$ buffered formalin for histopathological and immunohistochemical (IHC) examination. Kidney samples of all animals (cage experiment, field sampling) were routinely paraffin-embedded and $4 \mu \mathrm{m}$ sections were prepared for haematoxylin \& eosin (H\&E) staining. Suspicious cases were examined by IHC using a monoclonal anti-Tetracapsuloides bryosalmonae (PKX) antibody (AquaMAb-P01, Aquatic Diagnostics). Histopathological changes of the kidney were graded according to a common pathological grading system as 0 (none) to 6 (severe) (SchmidtPosthaus et al. 2012). Presence of T. bryosalmonae was examined on whole histological and IHC kidney sections, and infection intensity was classified as 0 (no parasites present on whole slide), 1 (single parasites), 2 (mild infection rate), 3 (mild to moderate infection rate), 4 (moderate infection rate), 5 (moderate to severe infection rate) or 6 (severe infection rate) at a magnification of 200 to $400 \times$ (Schmidt-Posthaus et al. 2012).

\section{Real-time PCR for detection of T. bryosalmonae DNA in kidney tissue}

Fish negative for $T$. bryosalmonae by histology and/or IHC were examined by real-time PCR. Two $20 \mu \mathrm{m}$ sections of paraffin-embedded material were 
deparaffinized. Lysis and extraction of total DNA was performed using the DNeasy Tissue Kit (Qiagen) according to the manufacturer's protocol. Samples were incubated with Proteinase $\mathrm{K}$ at $56^{\circ} \mathrm{C}$ and $450 \mathrm{rpm}$ overnight. The yield was determined by spectrophotometry using a NanoDrop photometer (NanoDrop Technologies). Real-time PCR was performed using SYBR GoTaq qPCR Master Mix (Promega) according to the manufacturer's instructions. The primer pair PKX3F (CTA AGT ACA TAC TTC GGT AGA) and PKX4R (CCG TTA CAA CCT TGT TAG GAA), described by Kent et al. (1998), was used. A positive control sample obtained from the kidney of clinically infected brown trout from other studies and a negative control using water were included in the PCR procedure. A 297 bp gene sequence of the small subunit ribosomal DNA was detected. Samples with a threshold cycle value of 35 or lower and a melting temperature equal to the positive control were classified as positive. To confirm the specificity of the real-time PCR, the realtime PCR was repeated without the dissociation stage and the PCR products were purified with NucleoSpin (Machery-Nagel). The products were checked on a $1 \%$ agarose gel for amplification and molecular weight. To verify the sequence, the PCR products were sent to Microsynth AG (Balgach, Switzerland) for sequencing. The identity of PCR products was determined by BLAST-n searching of the available sequences in the GenBank database (www.ncbi.nlm.nih.gov).

\section{Water temperature}

Water temperature was recorded every $2 \mathrm{~h}$ by temperature loggers located inside the cage, in the Wutach near the cage, and in the Ehrenbach near the fish sampling site (Fig. 1A). Mean values for each day were calculated and reported.

\section{Statistics}

PKD prevalence (\%) was calculated as the sum of T. bryosalmonae-positive animals per group divided by the total number of animals per group. The incidence of PKD describes the percentage of newly diseased individuals in the numerically defined group at risk for infestation over a limited time period. Significant differences between the groups were tested using a chi-square test at a $\mathrm{p} \leq 0.05$ significance level.
Parasite infection intensity was calculated as the sum of values for infection intensity per fish divided by the total number of infected animals. The mean pathology score was calculated as the sum of pathology scores per fish divided by the total number of affected animals.

\section{RESULTS}

\section{Water temperature}

In the Wutach, water temperature constantly exceeded $15^{\circ} \mathrm{C}$ for $38 \mathrm{~d}$ in a row from July to August (Fig. 1C). Following this extended warm period, water temperature exceeded $15^{\circ} \mathrm{C}$ over 10 additional non-consecutive days until October. As fish in the cage were exposed starting in the middle of July, when water temperature was already high, these animals experienced $39 \mathrm{~d}$ of water temperature above $15^{\circ} \mathrm{C}$. In the Ehrenbach, water temperatures of $15^{\circ} \mathrm{C}$ and higher were only reached on 8 days, and no longer than $5 \mathrm{~d}$ in a row (Fig. 1B).

\section{Cage experiment}

Animals sampled at the beginning of the experiment before exposure to river water and those kept in the hatchery were in good body condition, and showed no signs of Tetracapsuloides bryosalmonae infection. No T. bryosalmonae-positive trout could be identified by real-time PCR. No mortality was recorded in the group kept at the fish farm (Table 1).

Inside the cage in the River Wutach, 15 brown trout died during the first $73 \mathrm{~d}$ (Fig. 2, Table 1). Two animals that died during the first $14 \mathrm{~d}$ of the experiment showed no macroscopic signs of PKD, no histological kidney pathology, nor presence of $T$.

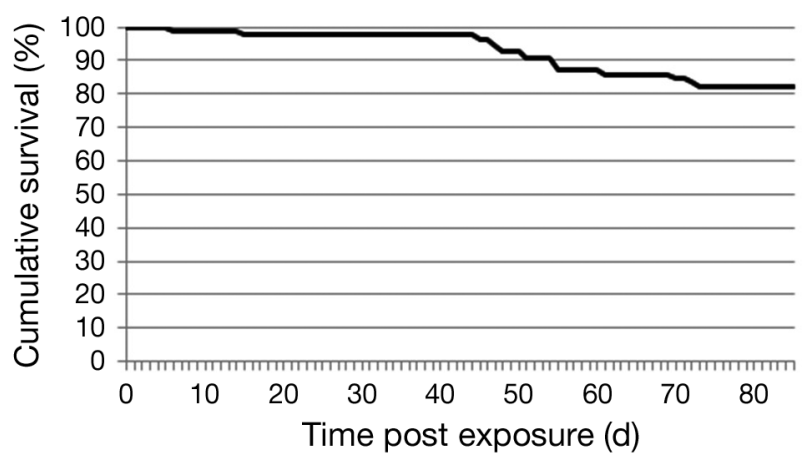

Fig. 2. Survivorship curve of brown trout Salmo trutta fario kept in the cage in the river Wutach 
bryosalmonae DNA. In all animals that died at later time points, infection with T. bryosalmonae was evident. Parasites were visible histologically in 9 animals. These 9 animals showed moderate to severe kidney lesions typical for an acute PKD infection (mean value $=3.33, \mathrm{SD}=1.12$; Fig. $3 \mathrm{~A}$, Table 1$)$. In the remaining 4 animals, autolysis was already advanced; thus in these fish, presence of parasite DNA could only be shown by real-time PCR. No other signs of concurrent disease were detected in these spontaneous deaths; therefore, mortality due to PKD was calculated at $15 \%$ (13/85). These PKDrelated mortalities occurred between 45 and $73 \mathrm{~d}$ post exposure (dpe; Fig. 2).

The surviving 70 brown trout were euthanized after $84 \mathrm{~d}$. Body condition was good (condition factor, mean value $=1.09, \mathrm{SD}=0.11$ ). Thirty-four of the 70 surviving brown trout (49\%) showed intact T. bryosalmonae by histology or IHC. Infection intensity in these animals varied between mild and moderate, at a mean intensity of $1.5(\mathrm{SD}=0.65)$. Using real-time PCR, T. bryosalmonae DNA was detected in an additional 12 brown trout.

Thirty-seven animals presented different patterns of kidney pathology. Sixteen trout showed acute renal changes with extrasporogonic parasites in the interstitium and intravascular thrombi composed of parasite stages, fibrin, and mainly macrophages and a few lymphocytes. Ten animals showed chronic active changes such as interstitial fibrosis, tubulonephrosis and tubuloneogenesis, together with an acute response to the disease as described above. In these animals, parasites were present in the interstitium, in the vessels, but also in the tubular lumen (Fig. 2D). However, detectable numbers of intratubular parasites were low. Six animals showed only solitary parasites in the interstitial tissue with only focal lesions. In 5 animals, kidney changes were already chronic

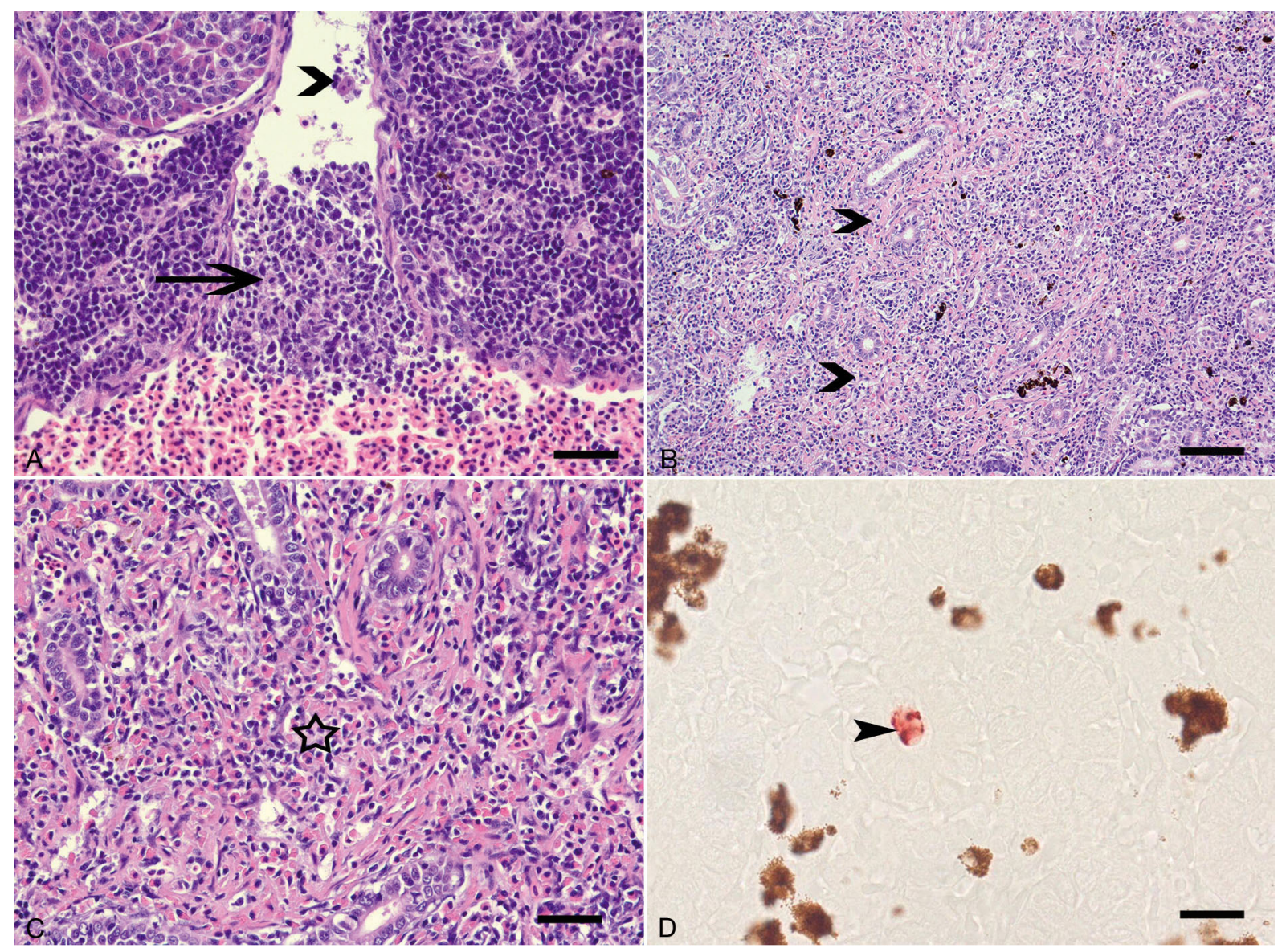

Fig. 3. Histological lesions found in brown trout Salmo trutta fario kept in the cage in river water. (A) Acute renal change with thrombus formation (arrow), thrombus consists of mainly macrophages, fewer lymphocytes and parasites (open arrowhead). (B) Chronic renal changes with fibrosis around tubuli and vessels (open arrowheads). (C) Higher magnification of chronic changes (star) with fibrosis and infiltration with macrophages and eosinophilic granular cells, hematoxylin \& eosin stain. (D) Immunohistochemical investigation showing positive parasite spores (arrowhead) in the tubular lumen. Scale bars $=(\mathrm{A}, \mathrm{C})$ $25 \mu \mathrm{m}$, (B) $50 \mu \mathrm{m}$, (D) $10 \mu \mathrm{m}$ 
(Fig. 3B,C), with spores in the tubular lumen (Fig. 3D) or no detectable parasites in vessels or the interstitial tissue. No signs of concomitant disease were present in any of the 70 animals.

Overall, PKD incidence was $69 \%$ (59 out of 85 exposed brown trout) after 3 mo of exposure (Table 1), which was not significantly different to PKD prevalence in wild brown trout (see below).

\section{Field sampling}

In the Ehrenbach, none of the examined brown trout showed any signs of a $T$. bryosalmonae infection by histology, IHC or real-time PCR. Kidney morphology was within normal limits in all examined fish.

In the Wutach, at the upstream and downstream locations, PKD prevalence was 82 and $80 \%$, respectively (Table 1). Infection intensity varied between mild and severe, with mean values of 2.8 and 3.5 for the upstream and downstream locations, respectively (Table 1). At the upstream location, infection with T. bryosalmonae was mostly associated with moderate to severe acute kidney lesions (Fig. 3A, Table 1). The mean pathology score was 3.6 (Table 1). One animal showed acute renal lesions and an interstitial severe fibrosis, interpreted as a chronic active lesion. At the downstream location, all infected animals showed acute kidney lesions. The mean pathology score was 3.75. At the upstream and downstream locations, parasites were located in the interstitial tissue and in the vessels.
Chi-square analysis comparing PKD prevalence between the 2 field sampling groups upstream and downstream of the cage and the PKD incidence in the cage showed no significant group differences $(\mathrm{p}=0.8921)$.

\section{DISCUSSION}

Previous studies hypothesized that increased PKDrelated mortality was a major contributor to the decline of brown trout populations (Zimmerli et al. 2007, Wahli et al. 2008, Schmidt-Posthaus et al. 2013), and YOY brown trout seemed to be especially affected (Burkhardt-Holm et al. 2005, Hari et al. 2006). In several brown trout populations in Switzerland, lower YOY brown trout densities could be correlated to the occurrence of PKD (Borsuk et al. 2006). In other countries (e.g. Denmark, Norway), the effect of Tetracapsuloides bryosalmonae infections on the population level is still under discussion (Mo et al. 2011, Skovgaard \& Buchmann 2012). Tetracapsuloides bryosalmonae-positive brown trout were found in high numbers in different fish populations by PCR; however, clinical signs were only rare (Mo et al. 2011, Skovgaard \& Buchmann 2012). Therefore, those authors suggested that $T$. bryosalmonae infections are not always detrimental for wild fish. However, mortality rates related to particular diseases in wild fish populations are difficult to measure as usually no post-mortem data can be collected. Therefore, the aim of the present study was to evaluate PKDrelated pathology and mortality in YOY brown trout

Table 1. Salmo trutta fario. Cage experiment and field sampling, different locations of sampling, length, prevalence of infected brown trout, infection intensity (shown as means \pm SD) and associated renal pathology (shown as means \pm SD), and proliferative kidney disease (PKD)-related mortality. Presence of Tetracapsuloides bryosalmonae (infection intensity) was classified as: 0 (no parasites present on whole slide), 1 (single parasites), 2 (mild infection rate), 3 (mild to moderate infection rate), 4 (moderate infection rate), 5 (moderate to severe infection rate) or 6 (severe infection rate) at a magnification of 200 to $400 \times$. Histopathological changes (pathology) of the kidney were graded as: 0 (none), 1 (scattered), 2 (mild), 3 (mild to moderate), 4 (moderate), 5 (moderate to severe) or 6 (severe)

\begin{tabular}{|c|c|c|c|c|c|c|c|}
\hline \multirow[t]{2}{*}{ Location } & & \multirow[t]{2}{*}{$\mathrm{n}$} & \multirow{2}{*}{$\begin{array}{l}\text { Length } \\
(\mathrm{cm})\end{array}$} & \multirow[b]{2}{*}{$\begin{array}{c}\text { Prevalence } \\
(\%)\end{array}$} & \multicolumn{2}{|c|}{ T. bryosalmonae in brown trout } & \multirow[b]{2}{*}{$\begin{array}{c}\text { Mortality } \\
(\%)\end{array}$} \\
\hline & & & & & $\begin{array}{l}\text { Infection } \\
\text { intensity }\end{array}$ & Pathology & \\
\hline \multicolumn{8}{|c|}{ Cage experiment } \\
\hline \multirow[t]{2}{*}{ Fish farm } & Starting control & 5 & $8.8 \pm 0.8$ & 0 & $0 \pm 0$ & $0 \pm 0$ & 0 \\
\hline & Negative control & 10 & $11.7 \pm 1.8$ & 0 & $0 \pm 0$ & $0 \pm 0$ & 0 \\
\hline Wutach & Caged animals & 85 & $11.2 \pm 1.3$ & 69 & $1.6 \pm 1.1$ & $2.3 \pm 1.4$ & 15 \\
\hline \multicolumn{8}{|c|}{ Field sampling } \\
\hline \multirow[t]{2}{*}{ Wutach } & Upstream & 11 & $10.2 \pm 1.0$ & 82 & $2.8 \pm 1.6$ & $3.6 \pm 1.7$ & Unknown \\
\hline & Downstream & 10 & $10.4 \pm 0.8$ & 80 & $3.5 \pm 2.1$ & $3.75 \pm 1.7$ & Unknown \\
\hline Ehrenbach & & 15 & $9.3 \pm 1.5$ & 0 & $0 \pm 0$ & $0 \pm 0$ & Unknown \\
\hline
\end{tabular}


kept in a cage in the River Wutach. Interestingly, mortality stayed as low as $15 \%$ in our experiment, despite the fact that $69 \%$ of caged fish became infected during the experimental period. In temperature-controlled aquaria using rainbow trout, mortality up to $85 \%$ was shown at constant water temperatures of $18^{\circ} \mathrm{C}$ (Schmidt-Posthaus et al. 2012) over a time period of 75 dpe. After 47 dpe, cumulative mortality had already reached $77 \%$ (Bettge et al. 2009). In our cage experiment, PKD-related mortality in brown trout occurred between 45 and 73 dpe (Fig. 2). Therefore, the onset of mortality was delayed compared to previous laboratory experiments using rainbow trout (Bettge et al. 2009). Species differences could be an explanation for this difference, with brown trout being less sensitive to the infection. In addition, water temperature higher than $15^{\circ} \mathrm{C}$ is thought to be critical for disease-related mortality (Bettge et al. 2009, Okamura et al. 2011). In our experiment, daily mean water temperature exceeded $15^{\circ} \mathrm{C}$ for $39 \mathrm{~d}$ inside the cage. Fish were exposed relatively late, starting in the middle of July, whereas native YOY trout are exposed to infestation much earlier. Low mortality could therefore also be due to an insufficient infection rate due to low spore density in the water. Spore release by bryozoans seems to be undulating instead of continuous, with a peak value in June/July (H. Hartikainen pers. comm.). Further research is needed to investigate this possible impact, e.g. by exposing brown trout in river water over the whole season with regular samplings during the exposure period to monitor disease development. However, incidence of infected animals at the end of our experiment was $69 \%$, similar $(p>0.05)$ to the disease prevalence found in wild brown trout at the nearby locations in the Wutach (80 and $82 \%$ ).

Additionally, lesions in caged fish were comparable to those occurring in wild fish in the same river during the time period of the experiment, and the severity of pathology was advanced in wild fish compared to caged animals. However, whereas wild brown trout and caged brown trout dying during the experiment showed acute kidney changes with intravascular extrasporogonic parasites, as well as parasites in the renal interstitium, caged fish sampled at the end of the experiment showed a high percentage $(41 \%)$ of chronic or chronic active lesions with spores already present inside renal tubuli. This indicates spore translocation into the tubular lumen (sporogonic stage) and spore excretion. The low number of detectable spores in the tubular lumen by IHC can be attributed to the fact that the monoclonal antibody (anti-Tetracapsuloides bryosalmonae [PKX] antibody,
AquaMAb-P01, Aquatic Diagnostics) used only partly detects sporogonic stages of the parasite, and therefore the number of intratubular spores was probably underestimated. Between the sampling of wild fish and the end of the cage experiment, there was a time delay of $4 \mathrm{wk}$, which might explain this morphological difference, with more chronic stages in caged animals. Therefore, these animals seemed to be survivors, already within a recovery stage of the disease. Unlike rainbow trout, brown trout are able to excrete intact spores, which can re-infect bryozoa (Morris \& Adams 2006, Grabner \& El-Matbouli 2008). In the field, additional stressors, such as concurrent diseases, can retard parasite development in the kidney and the kidney regeneration process in wild brown trout (Schmidt-Posthaus et al. 2013). Food competition can also be regarded as one additional stressor in the field. This stressor was not present in our study as animals in the cage were fed with artificial food, which was also reflected by the good body condition of caged brown trout.

Our results suggest that PKD in brown trout does not always result in high mortality under natural conditions. Additional research is needed to confirm these indications and to investigate possible applications in other river systems.

Acknowledgements. We thank the fishermen of the 'Oberes Wutachtal Stühlingen eV' (Stühlingen) for helping with the supervision of the trout in the cage; Peter Weisser and Patrick Wasem for their helpful comments; and Christopher Robinson, EAWAG Dübendorf, for analysing the temperature logger data.

\section{LITERATURE CITED}

Anderson CL, Canning EU, Okamura B (1999) 18S rDNA sequences indicate that PKX organism parasitizes bryozoa. Bull Eur Assoc Fish Pathol 19:94-97

Bagenal T (1978) Methods for assessment of fish production in fresh waters. Blackwell, Oxford

Bettge K, Wahli T, Segner H, Schmidt-Posthaus H (2009) Proliferative kidney disease in rainbow trout: time- and temperature-related renal pathology and parasite distribution. Dis Aquat Org 83:67-76

> Borsuk ME, Reichert P, Schager E, Peter A, Burkhardt-Holm $P$ (2006) Assessing the decline of brown trout (Salmo trutta) in Swiss rivers using a Bayesian probability network. Ecol Model 192:224-244

Burkhardt-Holm P, Giger W, Güttinger H, Ochsenbein U and others (2005) Where have all the fish gone? The reasons why the fish catches in Swiss rivers are declining. Environ Sci Tech 39:441A-447A

> Canning EU, Curry A, Feist SW, Longshaw M, Okamura B (2000) A new class and order of myxozoans to accommodate parasites of bryozoans with ultrastructural observations on Tetracapsula bryosalmonae (PKX Organism). J Eukaryot Microbiol 47:456-468 
Dash M, Vasemägi A (2014) Proliferative kidney disease (PKD) agent Tetracapsuloides bryosalmonae in brown trout populations in Estonia. Dis Aquat Org 109:139-148

El-Matbouli M, Hoffman RW (1994) Proliferative kidney disease (PKD) as an important myxosporean infection in salmonid fish. In: Pike AW, Lewis JW (eds) Parasitic diseases of fish. Samara Publishing, Tresaith, p 3-15

Feist SW, Bucke D (1993) Proliferative kidney disease in wild salmonids. Fish Res 17:51-58

Feist SW, Longshaw M, Canning EU, Okamura B (2001) Induction of proliferative kidney disease (PKD) in rainbow trout Oncorhynchus mykiss via the bryozoan Fredericella sultana infected with Tetracapsula bryosalmonae. Dis Aquat Org 45:61-68

Feist SW, Peeler EJ, Gardiner R, Smith E, Longshaw M (2002) Proliferative kidney diseases and renal myxosporidiosis in juvenile salmonids from rivers in England and Wales. J Fish Dis 25:451-458

Grabner DS, El-Matbouli M (2008) Transmission of Tetracapsuloides bryosalmonae (Myxozoa: Malacosporea) to Fredericella sultana (Bryozoa: Phylactolaemata) by various fish species. Dis Aquat Org 79:133-139

> Grabner DS, El-Matbouli M (2010) Tetracapsuloides bryosalmonae (Myxozoa: Malacosporea) portal of entry into the fish host. Dis Aquat Org 90:197-206

Hari R, Livingstone DM, Siber R, Burkhardt-Holm P, Güttinger $\mathrm{H}$ (2006) Consequences of climatic change for water temperature and brown trout populations in Alpine rivers and streams. Glob Change Biol 12:10-26

Hedrick RP, MacConnell E, de Kinkelin P (1993) Proliferative kidney disease of salmonid fish. Annu Rev Fish Dis 3: 277-290

> Hedrick RP, Baxa DV, De Kinkelin P, Okamura B (2004) Malacosporean-like spores in the urine of rainbow trout react with antibody and DNA probes to Tetracapsuloides bryosalmonae. Parasitol Res 92:81-88

Kent ML, Hedrick RP (1985) Development of the PKX myxosporean in rainbow trout Salmo gairdneri. Dis Aquat Org 1:169-182

Kent ML, Khattra J, Hervio DML, Devlin RH (1998) Ribosomal DNA sequence analysis of isolates of the PKX myxosporean and their relationship to members of the genus Sphaerospora. J Aquat Anim Health 10:12-21

Krkošek M, Ford JS, Morton A, Lele S, Myers RA, Lewis MA (2007) Declining wild salmon populations in relation to parasites from farm salmon. Science 318:1772-1775

Longshaw M, Feist SW, Canning EU, Okamura B (1999) First identification of PKX in bryozoans from the United Kingdom-molecular evidence. Bull Eur Assoc Fish Pathol 19:146-148

Longshaw M, Le Deuff RM, Harris AF, Feist SW (2002) Development of proliferative kidney disease in rainbow trout, Oncorhynchus mykiss (Walbaum), following shortterm exposure to Tetracapsula bryosalmonae infected bryozoans. J Fish Dis 25:443-449

Mo TA, Kaada I, Joranlid AK, Poppe TT (2011) Occurrence of Tetracapsuloides bryosalmonae in the kidney of smolts

Editorial responsibility: Dieter Steinhagen, Hannover, Germany of Atlantic salmon (Salmo salar) and sea trout (S. trutta). Bull Eur Assoc Fish Pathol 31:151-155

Morris DJ, Adams A (2006) Transmission of Tetracapsuloides bryosalmonae (Myxozoa: Malacosporea), the causative organism of salmonid proliferative kidney disease, to the freshwater bryozoan Fredericella sultana. Parasitology 133:701-709

Morris DJ, Adams A, Feist SW, McGeorge J, Richards RH (2000) Immunohistochemical and PCR studies of wild fish for Tetracapsula bryosalmonae (PKX), the causative organism of proliferative kidney disease. J Fish Dis 23: 129-135

> Morris DC, Morris DJ, Adams A (2002) Development of improved PCR to prevent false positives and false negatives in the detection of Tetracapsula bryosalmonae, the causative agent of proliferative kidney disease. J Fish Dis 25:483-490

> Okamura B, Anderson CL, Longshaw M, Feist SW, Canning EU (2001) Patterns of occurrence and 18S rDNA sequence variation of PKX (Tetracapsula bryosalmonae), the causative agent of salmonid proliferative kidney disease. J Parasitol 87:379-385

> Okamura B, Hartikainen H, Schmidt-Posthaus H, Wahli T (2011) Life cycle complexity, environmental change and the emerging status of salmonid proliferative kidney disease. Freshw Biol 56:735-753

Schmidt-Posthaus H, Bettge K, Forster U, Segner H, Wahli T (2012) Kidney pathology and parasite intensity in rainbow trout Oncorhynchus mykiss surviving proliferative kidney disease: time course and influence of temperature. Dis Aquat Org 97:207-218

> Schmidt-Posthaus H, Steiner P, Müller B, CasanovaNakayama A (2013) Complex interaction between proliferative kidney disease, water temperature and concurrent nematode infection in brown trout. Dis Aquat Org 104:23-34

Skovgaard A, Buchmann K (2012) Tetracapsuloides bryosalmonae and PKD in juvenile wild salmonids in Denmark. Dis Aquat Org 101:33-42

Sterud E, Forseth T, Ugedal O, Poppe TT and others (2007) Severe mortality in wild Atlantic salmon Salmo salar due to proliferative kidney disease (PKD) caused by Tetracapsuloides bryosalmonae (Myxozoa). Dis Aquat Org 77 : 191-198

> Wahli T, Knuesel R, Bernet D, Segner H and others (2002) Proliferative kidney disease in Switzerland: current state of knowledge. J Fish Dis 25:491-500

> Wahli T, Bernet D, Segner H, Schmidt-Posthaus H (2008) Role of altitude and water temperature as regulating factors for the geographical distribution of Tetracapsuloides bryosalmonae infected fish in Switzerland. J Fish Biol 73: 2184-2197

- Zimmerli S, Bernet D, Burkhardt-Holm P, SchmidtPosthaus H, Vonlanthen P, Wahli T, Segner H (2007) Assessment of fish health status in four Swiss rivers showing a decline of brown trout catches. Aquat Sci $69: 1-25$

Submitted: July 2, 2014; Accepted: January 30, 2015

Proofs received from author(s): April 23, 2015 